\title{
Foreign Policy Strategy of the Republic of Albania 1992 - 1997
}

\author{
Alban Përmeti \\ PhD Candidate, Faculty of History and Philology, Doctoral School "International Relation and Diplomacy" \\ permetialban@hotmail.com
}

\section{Doi:10.5901/mjss.2015.v6n2s1p498}

\begin{abstract}
With the change of systems from Communist to Democratic, the first democratic government led by Sali Berisha faced overwhelming challenges. On one hand the Democratic Party Government was taking over an economically devastated Albania, on the other hand Kosovo's issue was another difficult challenge falling on the shoulders of a democratic state in its road towards consolidation of democratic institutions. At the same time, Albania had to engage in the Euro Atlantic structures. This period would be described with ups and downs of its performance in relation to the internal relations but also with its foreign policy in the International arena in particular with its neighboring countries. Despite the crises and uncertainties the country was going through, both Internal and Foreign Affairs difficulties being were run in a consensual spirit regarding some priorities that remain constant throughout the post-communist period. These priorities were as follows: The opening of Albania with the World, Western Orientation of all foreign and development policies, normalization of relations with Great Powers, in particular Western Countries and Country members of Security Council of United Nations; balancing relation with neighbors based on new foundations grounded on National Interests as well as putting up Kosovo's issue as top agenda item, until its declaration of independence.
\end{abstract}

Keywords: Governing program, Strategic Program, Foreign Policy, Kosovo, NATO, Integration, EU

\section{Introduction}

In the political elections of March 22, 1992, peaceful transfer had been conducted from communism to political parliamentary pluralism and replacement of labor Party with Democratic Forces coming out as a result of political process initiated in November 1990. The head of the political forces was Democratic Party chaired by Sali Berisha. Government of Democratic Party, as a winning force from MARCH 22 Elections had overwhelming challenges ahead, in both terms either being internal or external. Internally this government was facing social economic challenges, as a result of a collapse of communist regime, whereas foreign policy issues were even harder, having in mind that during that time Kosovo's issue was the top priority of political agenda of this government. The platform of Democratic Party was aiming to accomplish substitution of dictatorship with pluralist parliamentary democracy, rule of law, and free market economy. This program was compiled and designed into 5 main chapters; first chapter encompassed reforms in political area of responsibility, within this scope independence and sovereignty of Albania were included; development of rule of law; legislative reform; judicial governance; local government; de-politization; army; Police and State Intelligence; Democratic Party's standpoint on Socialist Party and Allies of Socialist and least but not last viewpoint on war on Nazi fascist conquerors (Democratic Party contract with Albania, Printing House Tirana, 1995, p 3).

Reforms on Economy were included in the second chapters. Within this chapters the following issues were included: liberalization of prices and investments, quick currency convertibility, full-fledged liberalization of economy, quick privatization of economy, working relations, social assistance and migration, unblocking of foreign debt, opening the path to foreign investments, stimulation of rural development, foreign economic cooperation, investments in environment protection, construction and sheltering, completion of economic program (Democratic Party contract with Albania, Printing House Tirana, 1995, $p$ 3-4). The third chapter involved a special program related to agrarian politics of Democratic Government.

The Fourth Chapter engaged reforms in social area of responsibility. Within this chapter the following were included: "Democratic Party and persecuted political individuals"; "Democratic Party and Women"; Education and Science"; "culture and Sports"; health" (Democratic Party contract with Albania, Printing House Tirana, 1995, p 4).

Foreign policy was covered in the fifth chapter, the last chapter of the Democratic Party and its allies that came out from the March 22 elections 1992. Foreign Policy Program included the following aspects: "integration to European and Euro Atlantic Institutions, Cooperation with European Council, cooperation with European Union, cooperation with NATO 
and internationalization of Albanian national issue" (Democratic Party contract with Albania, Printing House Tirana, 1995, p 4).

\section{Strategic Program of Albanian Government regarding Foreign Policy}

Let us shed more light thoroughly on the program of Foreign Policy of the Democratic Party of 22 March 1992

The program of the Government specified: Foreign Policy of Democratic Party in its focus has moving the country towards democracy and free market economy by urging itself and being assisted economically and politically from internationals as well as internationalization of national issue ... We are - further specified - for Albania's engagement into European integration" (Democratic Party contract with Albania, Printing House Tirana, 1995, p 109).

As it is described in this definition Foreign Policy of the Democratic Government had intention to enable Foreign Service to produce valid and supportive viewpoints entrusted from internationals for political transformations, of economic development through foreign investments and economic international cooperation, internationalization of Albanian National Issue in the Balkans and engagement Albania into European processes. From the strategic point of View, there was clarity in relation to the set out objectives; though as 4 year Governing Program the ambition didn't match with implementing opportunities or mechanisms. However, Program didn't have a timeline and a matrix of clear division of institutional responsibilities to reach out the set objectives.

This ambiguity in calendar, stretched in time of the programme and non-delineation of institutional responsibilities was obvious in non-completion during 4 year mandate supposedly cooperation with EU and NATO, internationalization of National Issue in Balkans, in slow acceleration of foreign investments as well as in International Economic Cooperation but institutional non-coordination came out primarily due to the amendment of constitution in 1996 with its predictions relatively being confused in breaking down powers and institutional competencies.

Albanian Government in its 5 years of governance, referring to the concerned period followed a relatively proactive foreign policy, but often very confused in many respects, and this all due to lack of experience to govern in a democratic system, totally opponent what country had inherited in the years of communist dictatorship. By this time Albania had become member of some international organizations, member of OSCE and Council of Europe (Lani, Remzi. Schmidt, Fabian. Written in article: "Albanian Foreign Policy between Geography and History", magazine: The International Spectator. Volume XXXIII, No 2 (April-June 1998).

Relations with United States marked a positive beginning thus government of Albania had full support. The program of democratic government includes as following in the cooperation with United States:

"Seeking endorsement and safe political support from US thus United States compiles a priority of Albanian Foreign Policy" (Democratic Party contract with Albania, Printing House Tirana, 1995, p 112).

Among essential priorities relations of neighborhood with Italy were foreseen. Government was considering Italy a partner of significant importance (Democratic Party contract with Albania, Printing House Tirana, 1995, p 113). In general Italy acted very friendly with Albania in this delicate phase providing aid and political, diplomatic humanitarian and economical support, though Italy has been proactive in alleviating condition to the influx of emigration coming from Albanians. In this period of time, Italian President Scalfaro paid a visit to Albania; in addition the high level dialogue was followed with visits to Italy of Prime minister Aleksander Meksi and President Berisha.

Democratic Government predicted strengthening bilateral cooperation Albania- France thus during democratic governance the following agreement of friendship and cooperation has been signed between two countries, Memorandum of Understating had been signed in the area of Justice, Culture and assistance in Health and Education. Level of active bilateral cooperation has increased at senior level. President Berisha met President Miteran; Speaker of Parliament was received in Paris by President of National French Assembly; as well as Minister of Foreign Service of Albania Alfred Serreqi hosted in Tirana French Minister of Foreign Affairs Lamsur. Relations with France in general marked vitality and overall dynamic approach.

Among the priorities of Albanian Foreign Policy was improvement of bilateral relations with Great Britain. Political diplomatic dialogue was initiated. Ministers of Foreign Service, Hog, Coker and Klejborn paid visits to Albania. President Berisha paid a visit to London to meet Queen of England and Premier Minister. Foreign Investments agreements were signed on transport, tourism, culture and intensification cooperation marked success in the area of defence and security. In such circumstances British Government unblocked Albanian Gold held after the capture from the Second World War by German Nazis who hold it as payback for Corfu accident (Democratic Party contract with Albania, Printing House Tirana, 1995, p 115). 
Particular emphasis was paid to relations with Austria. "Our relations with Austria - emphasized by Democratic Government - our old friend, are being developed quickly and solidly" (Democratic Party contract with Albania, Printing House Tirana, 1995, $p$ 115). Political-Diplomatic Dialogue was stretched out at all levels thus president Berisha meet with Austrian President Klestil and Chancellor Vranicki. These visits were followed with signing bilateral agreements on Economy and Trade, Investments, Transport and Military and Consular Agreements. That time Austria granted to Albania the greatest aid compared to all other European Countries (Democratic Party contract with Albania, Printing House Tirana, 1995, p 115).

After a low level engagement period Democratic Government decided to set cooperation priorities with Turkey. "Friendly political economic, military and education cooperation with this friend country - emphasized by Democratic Government - goes very well". That has a very special meaning to us... only during the period 1992-1993 Turkey granted a humanitarian assistance worth of 31 million USD, along with the great technical, economical assistance in many areas" (Democratic Party contract with Albania, Printing House Tirana, 1995, p 115). Cooperation Albania- Turkey has been characterized by political diplomatic dialogue of highest levels. Presidents Demirel and Turgut Ozal paid visit to Albania. Former Prime-Minister Meksi and Chief Parliamentarian Arbnori visited Turkey. Various valuable documents and treaties have been signed such as Friendly Cooperation Treaty, Agreements on Foreign Investments, avoiding of dual taxation in the area of Justice, in Military for alleviating free visa regime, protocols on Economy, Law and Order, education, Culture, mass media, etc.

Relations of Albania with neighboring Greece were considered of particular interest. The program specified that "Democratic Party since the beginning paid special interest and continuous to do so friendly relations with our southerner neighbor." (Democratic Party contract with Albania, Printing House Tirana, 1995, p 116). The program was specific in highlighting that Albania didn't allow any provocation from Greece. Democratic Government expressed its appreciation for technical, financial, and humanitarian assistance government, institutions and Greek citizens provided to Albania in very difficult times. Assistance provided to Albanian emigrants in Greece was highly appreciated. For the first time Democratic Government brought up the issue of Cameria after 45 years of considering it a forgotten issue... Albanian Government program specified - brought up Cameria issue and shall insist in finding resolution" (Democratic Party contract with Albania, Printing House Tirana, 1995, p 117). In this period Albania had been visited by Karolos Papulias, whereas from our side Minister of Foreign Service Alfred Serreqi visited Greece. Albanian Government was in favor of dialogue in finding solution to all problems with Greece. Indeed from 1994 until the end of Meksi's governance, country has faced many problems with Greece. First the incident of Peshkepia, whereby Greek band killed Albanian militaries on duty at the border crossing point followed with Greek priest conflict deported by Albanian government therefore as a result Greek authorities conducted several times operations called "the broom" massive violent deportations of Albanian emigrants in Greece. The issue was addressed as a great concern to US and mediation from President Clinton was requested to stabilize the situation.

Among the countries considered with bilateral priority within European Union are countries such as Belgium, Netherlands, Sweden, and Finland. With all these countries, members of the European Union there was intensification of cooperation, further development in different areas and increase of diplomatic and political agenda (Democratic Party contract with Albania, Printing House Tirana, 1995, p 118-120).

Friendship with Hungary has been important from the Democratic Government of Albania. Between the two countries exchange visits were made at Presidential, Prime Ministry, Foreign Service, Ministry of Defense, Ministry of Economy, Agriculture levels etc. Between Albania and Hungary juridical cooperation instruments have been signed such as cooperation agreement in the areas such as agriculture, trade, removing double taxation, and defense and cooperation protocols.

Check Republic, Poland and Slovakia had special emphasis regarding the bilateral cooperation; these countries during the aforementioned period were involved in the Vishegrad troika. "Agreement of Vishegrad, signed in 1993 between Hungary, Poland, and Czechoslovakia aimed at accelerating overall cooperation within the spirit of EU criteria with the purpose to integrate three of the countries to EU as one block" (http://www.visegradgroup.eu/about).

Albania had a very close cooperation in the same line with regard to the acceleration pace of these three countries as a group. Certainly after the burst of conflict in the republics of Former Yugoslavia, trade economic cooperation with these countries has been reduced remarkably due to overwhelming obstacles and difficulties in transportation that derived from the sanctions imposed by Security Council of UN against Yugoslavia and later to Serbia specifically (UN Security Council Resolution on Sanction against, Serbia, 1994). Sanctions against Yugoslavia and later against Serbia brought impacts to all neighboring countries therefore economic-trade cooperation conditioned with the route transportation map through territories of Yugoslavia later Serbia has been reduced to zero. This imposed a very high economic damage to Albania and lowered cooperation with countries such as Chez Republic, Slovak Republic, Republic 
of Hungary and other republics around the conflict area that inevitably were supposed to respect sanctions imposed by Security Council of United Nations.

With other neighboring countries Albania marked positive progress with Bulgaria, Romania, Macedonia and Montenegro. With Bulgaria high level exchanges of Presidential, Prime-ministerial, and Ministerial proved to be very positive in different areas. Between the two countries friendship and Cooperation Treaty has been signed followed with the agreements in the economical-trade, military, investments levels as well as free visa regime agreement on service and diplomatic passports etc (Democratic Party contract with Albania, Printing House Tirana, 1995, p 122).

With Romania there was exchange of delegations at all potential levels of cooperation. Friendship Treaty between two countries has been signed followed on agreement on taxes and investments to avoid double taxation in the military, transport, culture area and to alleviate visa regime (Democratic Party contract with Albania, Printing House Tirana, 1995, p 123). With Croatia, totally new developments were registered due to the fact that it was e new country declaring independence in 1991. Mutual Exchange visits were paid at senior level to all potential areas of cooperation. Respective Embassies opened in Zagreb and Tirana, Friendship and Cooperation Treaty has been signed followed with bilateral agreements in the area of trade-economical areas on investments to avoid dual taxation in Military, Cultural areas and alleviating visa regime. With Slovenia new developments were made due to the fact that Slovenia becomes a sovereign and independent country in 1991, therefore bilateral cooperation acknowledged quick developments.

There was an exchange at the Presidential level between Presidents Berisha and Milan Kucanas well as Memorandum of Understanding were signed in the economical -trade area, on Transport, Military, Cultural Affairs including alleviating procedures in Visa-s.

With the Republic of Macedonia, developments marked novelties. This neighboring country has been established in 1991 right after the break-up of Yugoslavia. Around 700.000 Ethnic Albanians reside in Macedonia therefore Albanian Government adopted the following approach: "Our relations with Macedonia shall be developed having into account that stability is vital for the south Balkans therefore this stability as precondition a dialogue, understanding, fair ethnic relations between Macedonians and Albanians, i.e. guaranteeing and recognition of human and national rights of Albanians" (Democratic Party contract with Albania, Printing House Tirana, 1995, p 124).

In this spirit, meetings of senior Presidential levels were held, parliamentarians and executive officials that contributed in this regard. But, continuous process with Macedonia acknowledged constant crisis due to the fact that Constitution adopted from the initiative of Kiro Gligorov- president of Macedonia of that time, specifically highlighted in the preamble that Macedonia is a country of Macedonians." (Constitution of the Republic of Macedonia, 1991- Preamble). This provision of Constitution as specified avoided ethnic Albanian factor, which constituted a constitutional element state building for the country. Ignoring the multi-ethnic composition in the period 2000-2001 would provoke an armed bloody interethnic conflict which inevitably would impose changing the provisions of constitution of the Republic of Macedonia. Nevertheless, Foreign Policy of Albanian Government preserved and safeguarded its supportive poise in contribution to peace and stability of Macedonia, though it became more vocal in fulfilling and respecting national and human rights of Albanians in Macedonia. It was a very balanced relation offered from Tirana between the stability of Macedonia as a country and respecting the rights of Albanians within this country.

After the referendum of 2006 Montenegro declared its independence. In the first year's right after the changes, Montenegro was very close with Albania. But afterwards they supported Kosovo until the declaration of its independence.

In the Political Platform of Foreign Policy, Democratic Government of Tirana unveiled its platform for other countries outside Europe. Special emphasis was paid with Great Powers, members of the Security Council, with whom Albania had had solid relations but due to its political poise during the cold war (Prof. Dr. Lisen Bashkurti, "Diplomacy of Self-isolation", ADA, Tirana 2004, Book House GEER, p 271), these relations were either frozen or dead

Such relations were with Russian Federation and Peoples Republic of China. Regarding the relations with Russians the programme of Democratic Government stated as follows:

"Albania pays special attention to relations and cooperation with this great friendly country" (Democratic Party contract with Albania, Printing House Tirana, 1995, p 127). Indeed, except the visit of Parliamentary Speaker Pjeter Arbnori in Moscow, development of cooperation with Russia was very bleak. Particularly, beginning of the conflict and dissemination of Yugoslavia in which Serb Political viewpoints presented as a continuation of Russian interests in Balkans has frozen the cooperation between Russia and Albania. This status continued to be marginalized due to the conflict spreading in Kosovo, in which Russians supported openly up to Security Council defending Serbian Politics against independence of Kosovo.

Sort of different dynamics registered in the bilateral relations between Albania and Peoples Republic of China. The position of Democratic Government was as following: "Relations to this Great Country of extreme importance. Such relations marked progress and there is a will and interest in mutual increase in further development of this" (Democratic 
Party contract with Albania, Printing House Tirana, 1995, p 127).

This viewpoint was followed with development and expansion of cooperation between two countries, after a decade of cold relations - after 1978 (Prof. Dr. Lisen Bashkurti, "Diplomacy of Self -isolation", ADA, Tirana 2004, Book House GEER, p 367-375).

To increase the cooperation level Albania-China, numerous visits and exchanges were conducted at Presidential, Prime ministerial, levels including Ministry of Foreign Services, Industry and Defense. These visits concluded with signing series of legal agreements in the economical, investments and trade areas.

What attracts the attention and priorities of the democratic government is the focus on bilateral with third countries such as Israel, Malaysia or countries of Arab peninsula and Middle east such as Kuwait, Egypt, Saudi Arabia and Pakistan. With these countries a high level exchange in attracting investments in Albania. Despite all these efforts, cooperation with these countries in general didn't bring any impact to both political and economic aspect. It was obvious it was an imposed attempt or premature when it comes to the strategy which obviously Albanians were in lack of it. Everything remained in the level of political and diplomatic rhetoric or of a modest economic aid (Democratic Party contract with Albania, Printing House Tirana, 1995, p 125-128).

Most efficient proved to be bilateral development relations on all areas of responsibility with neighboring countries in particular with Turkey, Italy and Greece. With all these countries treaty of friendship and cooperation was signed including series of cooperation agreements in the areas of mutual interest. These three countries became in a way our strategic real partners. Analysis that can be made now, reflecting the period of two decades brings us to the conclusion that soon Albanian Foreign Policy in the first four years of Democratic Governance has been characterized from obvious lack of balancing and orientation. Accomplishment left room to more nationalist and extremist tensions. Relations with Italy remained unstable, and our western neighbor lost absolutely interest on Albania, at least until the collapse of the 1997. Greek -Albanian relations passed several phases and reached its lowest level in the last 18 years period. Albanian Government started to harshen its position regarding Kosovo issue, and of Albanians in Republic of Macedonia. At the same time when Berisha expressed doubts the obligation of its government for the Euro Atlantic future, he undertook very contradictory decision and absolutely personal in getting Albania's membership in the Islamic Conference. This event, aggravated relations of Albania with West particularly United States, by raising doubts among foreign partners as well as harsh reaction from the political opponents of that time.

Despite the crisis and difficult Internal and Foreign Policy was involved, Foreign Service managed to preserve consensual spirit. However Democratic Albania, with full political consensus opted for a foreign policy with certain priorities that remain constant throughout post-communist period. These priorities were as following: Opening up Albania with the World, leaving aside isolating legacy, western orientation of foreign and development policies which brought substantial change of the country, as well as normalization of relations with great powers, in particular with Western Governments- members of Security Council of United Nations; balancing relations with neighbors on new grounds based on national interests; putting up the issue of Kosovo in the priority agenda until its declaration of independence.

In our Foreign Policy two major dimensions were crystalized, regarding the period we are referring. Kosovo's problem was one of the two dimensions of the government of that time, in which foreign policy was focused. Second dimension was integration of the country to Euro Atlantic structures. Every government in the post-communist Albania, regardless of the political ideologies, two of the following issues were considered in its agenda as top priorities of the Foreign Service. Importance given by both political parties these issues, regardless of when they were taking power, with the objective to reach out the set objectives of the Albanian Foreign Service, the viewpoints were similar and unchanged. What changed and keeps changing is the way how Socialists or Democrats attempt to reach successfully these objectives. The position of Official Tirana in particular on Kosovo's issue, has impact and it is supported on solid grounds from great powers, allies that currently dominate world politics.

\section{Core issues of Foreign Service of Albania's Foreign Policy in the period 1992-1997}

Kosovo was a vital priority for Albania. From the status of Kosovo to a great extend depended national security of Albania and substantially its vital interest, survival. This was obvious in 1999 when Albania was found in the tragic events that wouldn't be able to face unless supported by the support of the West. Historically, Albania has characterized Kosovo's issue as an issue of Great Powers, considering in issue that overcomes its realistic opportunities to resolve it solely. This was the main reason that political elite of Kosovo, has addressed strong criticism to Tirana, by asking to undertake more responsibilities concerning this issue and to provide more clarity on this issue. Kosovo authorities asked Albania to view Kosovo's issue not as a problem that is to be resolved from outside forces but instead as a national issue (East European Reporter, Mars - April 1992, p. 58, declaration of Ali Aliut, The first representative of the Democratic League in Tirana). 
NATO was a strategic orientation for Albania. One of the major strategies in the Albanian Foreign Policy of Albania was determination to get NATO membership. With the new recognitions in the Prague Summit, new NATO structure focused more in the Balkans, by engaging majority of the Balkan Countries, indeed after that summit Balkan can be divided into two group countries in relations to NATO:

a. Countries involved in MAP (Albania, Croatia and Macedonia).

b. Countries that prepare themselves to enter individual NATO programs of PfP- (Bosnia and Herzegovina, Union Serbia-Montenegro and Kosovo).

Countries of Group (a), Albania, Croatia and Macedonia, encouraged and supported by US, a part of attending preparations on individual basis of MAP undertook a very important step in the group in the spring of 2003, signed the Adriatic chart. Adriatic Chart was inspired from the experience of Vishegrad countries Hungary-Czheckoslavakia-Poland, 1992 (Vishegrad Countries) (Find at: http://en.wikipedia.org/wiki/Visegr\%C3\%A1d Group) and the US-Baltic Charter (Find at: http://www.state.gov/www/regions/eur/ch_9801_baltic_charter.html). Therefore in this framework and based on the same experience, the Presidents of Albania, Croatia, Macedonia and President Bush proposed in the Summit of Prague in November 2002. The US President supported this initiative as it served the vision of a free and peaceful Europe.

Then-Secretary of State Colin Powell, together with his colleagues, the three Foreign Ministers signed the Adriatic Charter in Tirana, Albania, May 2, 2003. The Adriatic Charter, an initiative in the spirit of the 1998 U.S.-Baltic Charter, was proposed jointly by the Presidents of Albania, Croatia, and Macedonia to then-President Bush at the NATO Prague Summit in November 2002. Then-President Bush welcomed the Adriatic initiative as a strong contribution toward his vision of a Europe whole, free, and at peace The Charter builds on the achievements of the NATO Prague Summit by reinforcing continued U.S. support for the Alliance's "Open Door," underscoring the goal of Albania's, Croatia's, and Macedonia's eventual full integration into NATO and other Euro-Atlantic institutions.

- Underlines Albania's, Croatia's, and Macedonia's dedication to strengthening their individual and cooperative efforts to intensify domestic reforms that enhance the security, prosperity and stability of the region.

- Highlights the tremendous accomplishments of Albania, Croatia, and Macedonia on the path of Euro-Atlantic integration, outlines areas of continuing focus, and reiterates the intention of the United States to continue assisting the countries in implementing necessary reforms. Notes also that each aspirant country will be judged individually on its progress toward meeting standards for membership in Euro-Atlantic bodies.

- Reaffirms the parties' shared political commitment to strengthen democratic institutions, civil society, rule of law, market economies, and NATO-compatible militaries; to fight corruption and crime; and to protect human rights and civil liberties for all individuals in Albania, Croatia, Macedonia and the other countries of southeast Europe.

- Promotes the stability and Euro-Atlantic integration of all the countries of southeast Europe by bolstering political, defense, and economic cooperation among the partners and between them and their neighbors (Find at: http://www.state.gov/p/eur/rls/fs/112766.htm).

The evaluation to membership in European and Euro Atlantic structures depends on the individual performance of each aspiring country. Based on the individual reforms and the cooperation in the framework of the Adriatic Charter, the Alliance promoted the expansion process towards the Western Balkans in the beginning of 2008. This strategy was part of the agenda of the Bucharest Summit held in April 3-5, 2008. This summit treated many essential and international issues such as the issue of Kosovo, anti-missile defense system in Europe, the issue of Afghanistan and mainly the invitation to these countries to begin accession talks to join the Alliance.

Our region became part of the debate of NATO. The debate mainly encompassed the issue of Macedonia. The issue of Macedonia was a bilateral issue between Macedonia and Greece and it related to the name issue. Based in the Washington Charter, 1949, the decision to accession is taken consensually (Washington Treaty, 1949, Article 10, Washington D. C. - 4 April 1949, Find at: http://www.nato.int/cps/en/natohq/official_texts_17120.htm?selectedLocale=sq). Though negotiations took a considerable amount of time, it can be said that no compromised was achieved on the eve of the Summit. Therefore, Greece blocked the invitation for Macedonia.

Meanwhile, the Summit invited Albania and Croatia since the process should continue. The NATO security needed to further expand in the Western Balkans. The invitation is the final phases towards full membership. From the invitation to the signing of the Treaty is a period of negotiations and intensive reforms for Albania and Croatia. In the case of Albania, the reforms should include reforms of the electoral and legal systems as well as economy and military forces.

This period was of a great importance to Albania in its road to full membership in the Alliance. A year after receiving the invitation to membership, Albania was invited in the Bucharest Summit when it was given the member status with full rights. NATO membership was the greatest achievement of the post-communist Albanian Foreign Policy. 
This membership showed that our country had entered an irreversible political, democratic, economic and secure road according to the standards of NATO member countries. This achievement was valuable to the peace and security of the Western Balkans. Meanwhile, Macedonia remained out of the procedure for membership due to the above mentioned reasons.

EU integration was a strategic orientation to Albania. The second strategic priority based on a wide political and citizen consensus was and still remains the EU integration. This was a general orientation of all countries of the region.

Like all other countries that used to be under communist regime, Albania started its road toward European integration. The first steps were made by the government that resulted from the elections in March 1992 with the signing of the agreement with EU that would make possible the trade exchange and cooperation in different fields. This agreement made it possible for Albania to benefit funds from different EU projects, like the Phare project. 1992- 1997 was a very intensive period of time for the developments in Albania and before the elections of 1996 Albania was on the verge of signing the Stabilization and Association Pact (Find at: http://eeas.europa.eu/delegations/albania/eu_albania/political_relations/index_en.htm).

Regardless of the progress made during the first transition period in Albania, the events of 1996-1997, there was a restraint in the relations between Albania and the EU and many fields suffered drawbacks to come to a moment considered a regional approach of Brussels to the countries of South-eastern Balkans. The relations were characterized by limitations in the aspects of EU aid as well as between Albanian and the other member countries.

\section{Conclusions}

The foreign Policy of Albania in the years 1992- 1997 is characterized by instability, lack of experience and lack of vision towards the future. The core aspects of its policy are being found during this period. These two core issues included the Kosovo issue and the euro Atlantic integration of the country. These two issues were the vital interest of Albania. It is for the above mentioned reasons that Albania requested to become a NATO member. The moves of the Albanian diplomacy often went against the interests of the country and only a few steps were undertaken to improve things. The Balkan policy of Albania became more refined under the supervision and guidelines of the US and for a certain period of time Albania plays the role of a peace-making country in the region, a position later to be changed due to the manipulation of the election results in 1996 and after the harsh critics that it addressed to Washington. The policy of Albania towards Kosovo and Macedonia takes a nationalistic character. This kind of positioning worsens the Albanian US relations. The relations with neighboring countries remain frozen and only friendly agreements were signed with Italy and Greece, but the unsolved problems with Greece especially remain numerous during this period. There were no important developments with Italy. Lack of orientation seems clear from the decision to make Albania member of the Islamic Conference at a time when Albania pretended to gain membership in the Euro Atlantic structures after a long period of self-isolation. Albania became member of the European Council in July 1995 and it became the first South-eastern European country to request NATO membership and in 1994 it became member of the Program of Cooperation and Peace. The relation of Albania with EU suffered drawbacks. Conditionality was a dominant factor in Albanian's relations with EU as regard to aid from EU as well as its Member countries. The relations between Albania and EU started too re-established in 1999, a year that marked the entrance of our country into a new phase, the Stabilization and Association phase that was decided in the Helsinki meeting.

\section{References}

Democratic Party contract with Albania, Printing House Tirana, 1995.

Lani, Remzi. Schmidt, Fabian. Written in article: "Albanian Foreign Policy between Geography and History", magazine: The International Spectator. Volume XXXIII, No 2 (April-June 1998)

UN Security Council Resolution on Sanction against, Serbia, 1994.

Constitution of the Republic of Macedonia, 1991- Preamble.

Prof. Dr. Lisen Bashkurti, "Diplomacy of Self-isolation", ADA, Tirana 2004, Book House GEER.

East European Reporter, March - April 1992, declaration of Ali Aliu, The first representative of the Democratic League in Tirana.

European Commission Progress Report 2006 - Albania, Brussels, 08-11-2006, SEC (2006) 1383.

Maastricht Treaty, 1992.

Copenhagen Summit, 1993, Copenhagen Criterias.

Summit of Madrid, Madrid Criteria, 1995.

Euro barometer.

European Commission, Progress Report on Albania, 2010, Brussels, 09 November 2010, SEC (2010) 1335.

Adriatic Charter, Tirana, May, 2003. 
http://www.nato.int/cps/en/natolive/official_texts_8443.htm.

Washington Treaty, 1949, Article 10, Washington D. C. - 4 April 1949, see: http://www.nato.int/cps/en/natohq/official_texts_17120.htm ?selectedLocale $=\mathrm{sq}$

http://eeas.europa.eu/delegations/albania/eu_albania/political_relations/index_en.htm.

http://www.visegradgroup.eu/about

http://en.wikipedia.org/wiki/Visegr\%C3\%A1d_Group

http://www.state.gov/www/regions/eur/ch_9801_baltic_charter.html 